\title{
ANALISIS FAKTOR YANG MEMPENGARUHI WISATAWAN MANCANEGARA MEMILIH MODA TRANSPORTASI SEPEDA MOTOR DI KAWASAN KUTA SELATAN
}

\author{
I Made Aswin Ananta Sena ${ }^{1}$, N.M.S. Wijaya ${ }^{2}$, N.G.A.S. Dewi ${ }^{3}$ \\ Email: anantaaswin@outlook.com ${ }^{1}$,sofia_ipw@unud.ac.id ${ }^{2}$, susrami_ipw@unud.ac.id ${ }^{3}$ \\ ${ }^{1,2,3}$ Program Studi Sarjana Industri Perjalanan Wisata, Fakultas Pariwisata, Universitas Udayana
}

\begin{abstract}
The study aims to analyze the factors that affect tourist in choosing a motorcycle as a mode of transportation in South Kuta area. Data were collected using survey online questionnaires. The number of respondents was 100 international tourists. The methodologies used were descriptive statistics, factor analysis using the IBM SPSS 26.0 for Windows application. The result of the study shows that there are two factors, which influence international tourists to choose the motorcycle as the transportation mode in South Kuta area. The two factors are external and internal factors. The external factor consists of the street width, the convenience of renting the transportation mode, availability of the parking area, the traffic density, the transportation cost, and the reliability. The internal factor are family recommendation, easy to used, own a driving license, budget, and driving range. Based on the result of factor analysis, the external factor as a dominant factor that influences international tourists to choose motorcycle as transportation mode in South Kuta Area.
\end{abstract}

\begin{abstract}
Abstrak: Penelitian ini bertujuan untuk menganalisis faktor apa saja yang dapat mempengaruhi wisatawan mancanegara memilih menggunakan moda transportasi sepeda motor di kawasan Kuta Selatan. Dalam menentukan sampel, peneliti menggunakan metode purposive sampling yang dimana peneliti memberikan kuesioner secara dalam jaringan kepada 100 orang responden. Teknik analisis data yang digunakan adalah teknik analisis data deskriptif kuantitatif dan analisis faktor dengan menggunakan aplikasi IBM SPSS 26.0 for Windows Hasil penelitian menunjukkan bahwa terdapat dua faktor yang mempengaruhi wisatawan mancanegara memilih moda transportasi sepeda motor di kawasan Kuta Selatan, yaitu Faktor Eksternal dan Faktor Internal. Faktor Eksternal terdiri dari lebar jalan, kemudahan untuk menyewa, ketersediaan ruang parkir, cepat, kepadatan lalu lintas biaya transportasi, dan keandalan. Sedangkan Faktor Internal meliputi rekomendasi keluarga, kemudahan untuk digunakan, kepemilikan SIM, anggaran, dan jangkauan. Berdasarkan hasil analisis faktor, Faktor Eksternal merupakan faktor yang dominan dalam mempengaruhi wisatawan mancanegara memilih moda transportasi sepeda motor di kawasan Kuta Selatan.
\end{abstract}

Keywords: factor analysis, mode choice, motorcycle, tourist effect, transportation.

\section{PENDAHULUAN}

Bali merupakan salah satu pulau yang memiliki beraneka ragam daya tarik wisata baik daya tarik wisata alam maupun daya tarik wisata buatan yang dimana kabupaten Badung termasuk ke dalam salah satunya. Terdapat banyak daya tarik wisata yang terdapat di kabupaten Badung, khususnya kawasan Kuta Selatan yang meliputi Taman Budaya Garuda Wisnu Kencana, Pantai Pandawa, Pantai Balangan, Saat ini terdapat berbagai jenis moda transportasi yang memudahkan wisatawan untuk menjangkau daya tarik yang terdapat di kawasan Kuta Selatan, salah satunya adalah moda transportasi sepeda motor.

Kepadatan lalu lintas yang terdapat di Bali, khususnya kawasan Kuta Selatan menjadi salah satu penyebab wisatawan mancanegara cenderung untuk memilih moda transportasi sepeda motor. Terdapat beberapa titik kemacetan di kawasan Kuta Selatan 
diantaranya adalah simpang udayana dan jalan raya uluwatu. Selain itu, permasalahan yang timbul adalah jumlah kendaraan yang terdapat di kabupaten Badung sangat padat. Data yang dihimpun dari Badan Pusat Statistik Provinsi Bali (2018) menyatakan dalam rentang waktu tahun 2013 sampai 2017 terdapat 2.814.230 unit kendaraan sepeda motor yang terdapat di kabupaten Badung, termasuk di kawasan Kuta Selatan. Jika dibandingkan dengan panjang jalan yang hanya $124,80 \mathrm{~km}$, tentunnya jumlah tersebut timpang dan menjadi salah satu penyebab kepadatan lalu lintas.

Pada tahun 2018 terjadi 1089 kasus kecelakaan lalu lintas di provinsi bali dan $77 \%$ dari kasus kecelakaan tersebut melibatkan sepeda motor. Selain itu terdapat 34 kasus kecelakaan lalu lintas yang melibatkan warga negara asing dengan rincian empat orang meninggal, tiga orang luka berat, dan 27 orang mengalami luka ringan. Disamping fenomena tersebut, terlihat masih banyak wisatawan khususnya wisatawan mancanegara yang masih memilih menggunakan moda transportasi sepeda motor.

Berdasarkan fenomena tersebut, peneliti merasa bahwa perlu dilakukan penelitian mengenai "Analisis Faktor yang Mempengaruhi Wisatawan Mancanegara Memilih Moda Transportasi Sepeda Motor di Kawasan Kuta Selatan". Hasil dari penelitian ini diharapkan dapat menjadi bahan pertimbangan bagi pemangku kebijakan dalam membuat regulasi mengenai transportasi masa dan dapat dijadikan sebagai refrensi kepada pemilik usaha penyewaan sepeda motor untuk memperketat penyewaan kendaraan. Selain itu diharapkan penelitian ini dapat menjadi refrensi penelitian yang akan datang.

\section{METODE PENELITIAN}

Penelitian ini dilakukan di kawasan Kuta Selatan, tepatnya di beberapa daya tarik wisata yang terdapat di kawasan Kuta Selatan. Dikarenakan terjadinya pandemi covid-19 pada saat penelitian, kuesioner disebarkan secara online melalui grup yang terdapat di jejaring sosial seperti Uluwatu Community, Bukit Community, Nusa Dua Community, dan Bali Expat Community. Selain itu kuesioner juga disebarkan melalui surat elektronik.
Penelitian ini terdapat empat faktor awal, diantaranya: 1. Faktor Pengguna Jalan yang terdiri dari Kepemilikan SIM $\left(\mathrm{X}_{1}\right)$, Rekomendasi Keluarga $\left(\mathrm{X}_{2}\right)$, dan Anggaran $\left(\mathrm{X}_{3}\right)$; 2. Faktor Ciri Perjalanan terdiri dari Kemudahan Untuk Digunakan $\left(\mathrm{X}_{4}\right)$ dan Kemudahan Untuk Menyewa $\left(\mathrm{X}_{5}\right)$; 3. Faktor Fasilitas Moda yang terdiri dari Biaya Transportasi $\left(\mathrm{X}_{6}\right)$, Ketersediaan Ruang Parkir $\left(\mathrm{X}_{7}\right)$, Cepat $\left(\mathrm{X}_{8}\right)$, dan Keandalan $\left(\mathrm{X}_{9}\right) ; 4$. Faktor Kota dan Zona yang terdiri dari Daerah Berkendara $\left(\mathrm{X}_{10}\right)$, Jangkauan $\left(\mathrm{X}_{11}\right)$, Kepadatan Lalu Lintas $\left(\mathrm{X}_{12}\right)$, dan Lebar Jalan $\left(\mathrm{X}_{13}\right)$.

Teknik pengumpulan data yang digunakan pada penelitian ini diantaranya dengan melakukan observasi secara langsung di kawasan Kuta Selatan, penyebaran kuesioner secara online dengan menggunakan skala likert, dan studi kepustakaan.

Sampel yang digunakan dalam penelitian ini berjumlah 100 orang wisatawan yang pernah memilih moda transportasi sepeda motor di kawasan Kuta Selatan. Jumlah tersebut sesuai dengan pernyataan Hair et.al. (2009) yang menyatakan bahwa dalam analisis faktor, jumlah sampel dalam analisis faktor tidak kurang dari 50 dan sebaiknya berjumlah 100 atau lebih. Sampel dalam penelitian ini ditentukan secara purposive yang dimana wisatawan mancanegara pernah memilih moda transportasi sepeda motor di kawasan Kuta Selatan.

\section{HASIL DAN PEMBAHASAN}

Setelah dilakukan penelitian terhadap 100 responden penelitian, didapatkan hasil penelitian. Hasil penelitian berdasarkan karakteristiknya akan dijabarkan sebagai berikut. Berdasarkan jenis kelaminnya, wisatawan mancanegara yang memilih moda transportasi sepeda motor terdiri dari $51 \%$ responden berjenis kelamin perempuan dan 49\% responden berjenis kelamin laki-laki. Berdasarkan rentang usianya, jumlah wisatawan tertinggi adalah wisatawan dengan rentang usia 17 - 25 tahun sebanyak $32 \%$. Sedangkan jumlah wisatawan terendah adalah wisatawan dengan rentang usia $>55$ tahun sebesar 4\%. Berdasarkan daerah asalnya, wisatawan yang berasal dari jerman mendominasi sebanyak 21\%. Berdasarkan 
tingkat pendidikannya, wisatawan yang memiliki tingkat pendidikan sarjana berjumlah lebih banyak dengan persentase $57 \%$. Sedangkan jumlah terendah adalah wisatawan dengan tingkat pendidikan diploma sebesar $10 \%$. Berdasarkan pekerjaannya, wisatawan yang berprofesi sebagai pegawai mendominasi sebanyak 55\%. Berdasarkan pendapatan per bulannya, wisatawan dengan pendapatan lebih dari $\$ 500$ berjumlah lebih banyak dengan persentase sebesar 74\%. Sedangkan wisatawan terendah adalah wisatawan dengan pendapatan antara $\$ 100-\$ 200$ berjumlah $7 \%$. Berdasarkan pengeluaran per harinya, wisatawan yang mendominasi adalah wisatawan yang memiliki pengeluaran per hari Rp. 100.000 - Rp. 200.000 dengan persentase $34 \%$. Sedangkan wisatawan yang berjumlah sedikit adalah wisatawan yang memiliki pengeluaran per hari dibawah Rp. 100.000 dengan persentase $13 \%$. Berdasarkan frekuensi berkunjungnya, wisatawan yang berkunjung lebih dari lima kali mendominasi dengan persentase sebesar $47 \%$. Berdasarkan tujuan perjalanannya, wisatawan yang memiliki tujuan untuk berlibur mendominasi dengan persentase sebear 59\%. Berdasarkan pengorganisasian perjalanannya, wisatawan yang mengatur perjalanannya sendri mendominasi dengan persentase sebesar $85 \%$.

Setelah diketahui karakteristik dari wisatawan, selanjutnya dilakukan pengujian validitas dan reliabilitas terhadap instrumen penelitian. Dilakukan pengujian validitas terhadap 13 indikator penelitian. Hasil pengujian validitas tersebut menunjukkan bahwa 12 indikator penelitian valid dan dapat dilanjutkan ke tahap berikutnya. Sedangkan satu indikator penelitian tidak valid dan tidak dapat dilakukan ke tahap pengujian berikutnya. Indikator tersebut adalah Daerah berkendara $\left(\mathrm{X}_{10}\right)$. Selanjutnya, dilakukan pengujian reliabilitas terhadap 12 indikator yang valid. Didapatkan hasil bahwa ke-12 indikator tersebut dinyatakan reliabel dan dapat dilanjutkan ke pengujian selanjutnya. Hal tersebut memiliki arti bahwa jika ke-12 indikator tersebut dilakukan pengujian kembali akan menunjukkan hasil yang konsisten.
Selanjutnya dilakukan analisis skala likert untuk mengetahui gambaran secara umum terhadap faktor yang mempengaruhi wisatawan mancanegara memilih moda transportasi sepeda motor di kawasan Kuta Selatan. Hasil analisis skala likert menyebutkan bahwa faktor Cepat $\left(\mathrm{X}_{8}\right)$ merupakan faktor yang paling berpengaruh secara umum terhadap keputusan wisatawan mancanegara memilih moda transportasi sepeda motor dengan skala 3.56. Sedangkan faktor yang tidak berpengaruh secara umum adalah faktor Rekomendasi Keluarga $\left(\mathrm{X}_{2}\right)$ dengan skala 2.68.

Analisis faktor dalam penelitian ini dilakukan ke dalam beberapa tahapan. Tahapan pertama dilakukan identifikasi terhadap 13 indikator yang menjadi penentu wisatawan mancanegara memilih moda transportasi sepeda motor di kawasan Kuta Selatan. Tahapan kedua, dilakukan perumusan masalah dengan melakukan tiga pengujian, antara lain Uji Bartlett's, Uji Kaiser-Meyer Olkin (KMO), dan Uji Measure of Sampling Adequacy (MSA). Pada Uji Bartlett's, didapatkan hasil sebesar 635.530 dengan tingkat signifikansi sebesar 0.000 . Hal ini memiliki arti bahwa seluruh indikator memiliki korelasi satu dengan lainnya dan peluang terjadinya kesalahan adalah sebesar 0\%. Pada uji KMO, didapatkan hasil pengujian sebesar 0.861 yang dimana hal tersebut sudah memenuhi syarat pengujian yaitu nilai harus lebih dari 0.5 dan dapat dilanjutkan ke tahap pengujian MSA. Pada pengujian MSA, didapatkan hasil bahwa ke-12 indikator yang diujikan memenuhi syarat pengujian MSA yang dimana ke-12 indikator memiliki nilai MSA lebih dari 0.5. Hal ini memiliki arti bahwa seluruh indikator dapat diproses ke tahap pengujian selanjutnya.

Tahap ketiga dalam analisis faktor adalah penentuan jumlah faktor yang akan digunakan dalam penelitian. Pada tahapan ini terbentuk dua faktor dari 12 indikator pembentuk faktor yang mempengaruhi wisatawan mancanegara memilih moda transportasi sepeda motor di kawasan Kuta Selatan. Kedua faktor tersebut memiliki nilai eigenvalue sebesar $>1$ yaitu 6.031 dan 1.056 yang dimana faktor terbentuk menjelaskan 
$59.057 \%$ total varian variabel mempengaruhi wisatawan mancanegara memilih moda transportasi sepeda motor di kawasan Kuta Selanjutnya.

Setelah menentukan jumlah faktor, tahapan selanjutnya yang akan dilakukan adalah rotasi faktor dengan metode rotasi varimax. Berdasarkan hasil rotasi yang telah dilakukan, seluruh 12 indikator penelitian memenuhi syarat pengujian dikarenakan memiliki nilai loading factor lebih dari 0.5. Selajutnya 12 indikator penelitian akan disebar ke dua faktor yang telah terbentuk dengan menggunakan metode Principal Component Analysis (PCA). Hasil dari penyebaran tersebut adalah terdapat tujuh indikator yang termasuk faktor pertama dan lima indikator yang termasuk ke dalam faktor kedua. Faktor pertama terdiri dari Lebar Jalan $\left(\mathrm{X}_{13}\right)$, Kemudahan Untuk Menyewa $\left(\mathrm{X}_{5}\right)$, Ketersediaan Ruang Parkir $\left(\mathrm{X}_{7}\right)$, Cepat $\left(\mathrm{X}_{8}\right)$, Kepadatan Lalu Lintas $\left(\mathrm{X}_{12}\right)$, Biaya Transportasi $\left(\mathrm{X}_{6}\right)$, dan Keandalan $\left(\mathrm{X}_{9}\right)$. Sedangkan untuk faktor kedua terdiri dari Rekomendasi Keluarga $\left(\mathrm{X}_{2}\right)$, Kemudahan Untuk Digunakan $\left(\mathrm{X}_{5}\right)$, Kepemilikan SIM $\left(\mathrm{X}_{1}\right)$, Anggaran $\left(\mathrm{X}_{3}\right)$, Jangkauan $\left(\mathrm{X}_{11}\right)$.

Tahapan terakhir dari analisis faktor adalah interpretasi faktor yang dimana faktor yang sudah terbentuk diberikan nama sesuai dengan indikator yang membentuk faktor tersebut. Adapun hasil interpretasi faktor dapat dilihat pada Tabel 1 berikut.

Tabel 1.

Faktor-faktor yang Mempengaruhi Wisatawan Mancanegara Memilih Moda Transportasi Sepeda Motor di Kawasan Kuta Selatan

\begin{tabular}{|c|c|c|c|c|c|}
\hline $\begin{array}{l}\mathrm{N} \\
\mathrm{o} .\end{array}$ & $\begin{array}{l}\text { Nama } \\
\text { Faktor }\end{array}$ & Indikator & $\begin{array}{c}\text { Eigenva } \\
\text { lue }\end{array}$ & $\begin{array}{l}\text { Loadi } \\
n g \\
\text { Facto } \\
r\end{array}$ & $\begin{array}{l}\text { Persent } \\
\text { ase } \\
\text { Variasi } \\
(\%)\end{array}$ \\
\hline \multirow[t]{3}{*}{1.} & \multirow[t]{3}{*}{$\begin{array}{c}\text { Ekster } \\
\text { nal }\end{array}$} & $\begin{array}{l}\text { Lebar } \\
\text { Jalan } \\
\left(\mathrm{X}_{13}\right)\end{array}$ & \multirow[t]{3}{*}{6.031} & 0.817 & 50.258 \\
\hline & & $\begin{array}{l}\text { Kemudah } \\
\text { an untuk } \\
\text { menyewa } \\
\left(\mathrm{X}_{5}\right)\end{array}$ & & 0.763 & \\
\hline & & $\begin{array}{l}\text { Ketersedi } \\
\text { aan } \\
\text { Ruang } \\
\text { Parkir } \\
\left(\mathrm{X}_{7}\right)\end{array}$ & & 0.762 & \\
\hline
\end{tabular}

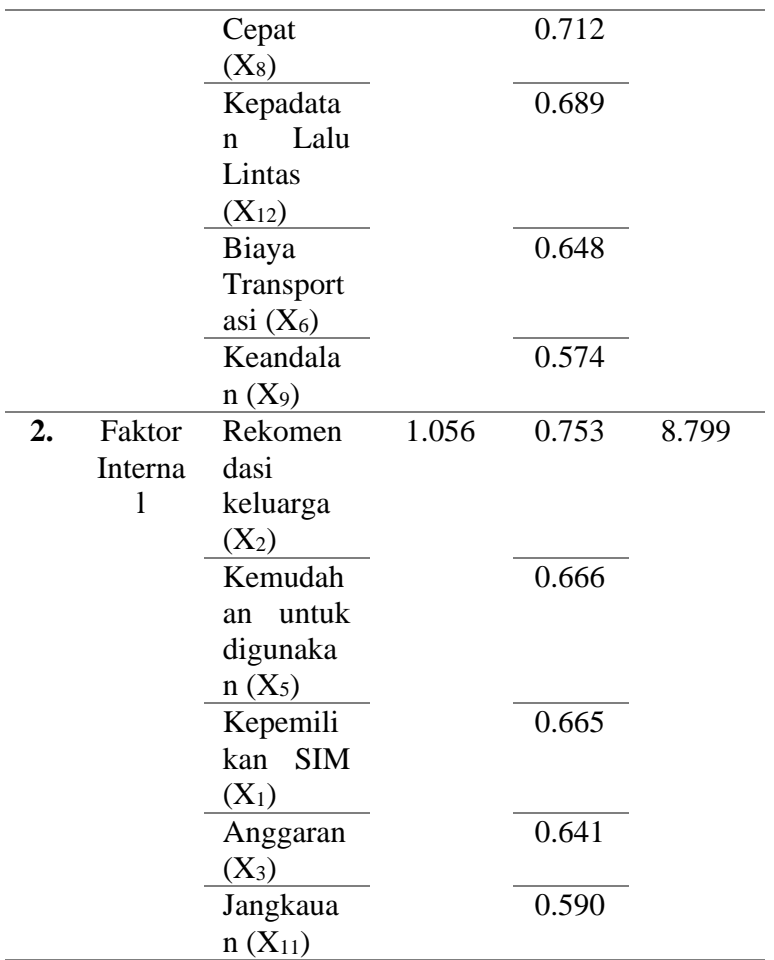

Sumber: Hasil Penelitian, 2020

Berdasarkan Tabel 1 di atas, dapat ditemukan dua faktor yang terdiri dari 12 indikator pembentuk. Dua faktor yang sudah terbentuk diberi nama sesuai dengan indikator yang membentuk faktor tersebut. Adapun penamaan faktor tersebut akan diuraikan sebagai berikut.

a. Faktor 1

Faktor pertama diberi nama Faktor Eksternal dengan memiliki nilai eigenvalue 6.031. Adapun Faktor Eksternal terbentuk dari Lebar Jalan $\left(\mathrm{X}_{13}\right)$, Kemudahan Untuk Menyewa $\left(\mathrm{X}_{5}\right)$, Ketersediaan Ruang Parkir $\left(\mathrm{X}_{7}\right)$, Cepat $\left(\mathrm{X}_{8}\right)$, Kepadatan Lalu Lintas $\left(\mathrm{X}_{12}\right)$, Biaya Transportasi $\left(\mathrm{X}_{6}\right)$, dan Keandalan $\left(\mathrm{X}_{9}\right)$.

b. Faktor 2

Faktor kedua diberi nama Faktor Internal dengan memiliki nilai eigenvalue 1.056. Adapun Faktor Internal terdiri dari Rekomendasi Keluarga $\left(\mathrm{X}_{2}\right)$, Kemudahan Untuk Digunakan $\left(\mathrm{X}_{4}\right)$, Kepemilikan SIM $\left(\mathrm{X}_{1}\right)$, Anggaran $\left(\mathrm{X}_{3}\right)$, Jangkauan $\left(\mathrm{X}_{11}\right)$.

Faktor Dominan yang Mempengaruhi Wisatawan Mancanegara Memilih Moda Transportasi Sepeda Motor di Kawasan Kuta Selatan 
Faktor dominan yang mempengaruhi wisatawan mancanegara memilih moda transportasi sepeda motor di kawasan Kuta Selatan dapat dilihat dari nilai eigenvalue tertinggi yaitu Faktor Eksternal yang memiliki nilai 6.031 dan percent of variance sebesar $50.258 \%$

Faktor Eksternal dalam penelitian ini terdiri dari tujuh indikator pembentuk yang mempengaruhi wisatawan mancanegara memilih moda transportasi sepeda motor. Indikator pertama yaitu Lebar Jalan. Hal tersebut mempengaruhi wisatawan mancanegara untuk memilih moda transportasi sepeda motor dikarenakan lebar jalan yang terdapat di kawasan Kuta Selatan tidak lebar dan cenderung sempit

Indikator kedua yang berpengaruh adalah Kemudahan Untuk Menyewa. Dalam hal ini,wisatawan dapat dengan mudah untuk menemukan tempat penyewaan moda transportasi sepeda motor.

Indikator ketiga yang berpengaruh adalah Ketersediaan Ruang Parkir. Hal tersebut dikarenakan ruang parkir yang tersedia untuk moda transportasi Sepeda Motor di kawasan Kuta Selatan berjumlah banyak dan hal tersebut dapat memudahkan wisatawan ketika berkunjung ke sebuah daya tarik yang berada di kawasan Kuta Selatan.

Indikator keempat yang berpengaruh adalah Cepat. Wisatawan merasa bahwa moda transportasi sepeda motor merupakan transportasi yang fleksibel dan efisien sehingga wisatawan dapat dengan cepat menjangkau daya tarik yang akan mereka datangi.

Indikator kelima yang mempengaruhi wisatawan mancanegara memilih moda transportasi sepeda motor adalah Kepadatan Lalu Lintas. Lalu lintas yang terdapat di kawasan Kuta Selatan sangatlah padat sehingga wisatawan tidak ingin membuang waktu yang cukup lama berada di jalan. Oleh karena itu wisatawan memilih moda transportasi sepeda motor dan dapat menghindar dari kepadatan lalu lintas.

Indikator keenam yang mempengaruhi wisatawan mancanegara memilih moda transportasi sepeda motor adalah Biaya Transportasi. Wisatawan merasa bahwa biaya transportasi yang dikeluarkan untuk menggunakan moda transportasi sepeda motor lebih murah dibandingkan biaya yang harus dikeluarkan ketika menggunakan moda transportasi lainnya seperti taksi atau mobil dengan supir. Wisatawan merasa bajhwa biaya yang harus dikeluarkan jika memilih menggunakan moda transportasi taksi maupun mobil dengan supir lebih mahal dibandingkan dengan memilih menggunakan moda transportasi sepeda motor.

Indikator terakhir yang berpengaruh adalah Keandalan. Wisatawan merasa bahwa hal yang mempengaruhi mereka dalam memilih moda transportasi sepeda motor adalah keandalan mereka untuk mengendarai moda transportasi tersebut secara mandiri. Rasa handal yang dirasakan oleh wisatawan dapat saja dipicu oleh indikator-indikator lainnya yang terdapat pada Faktor Eksternal.

\section{SIMPULAN DAN SARAN \\ Simpulan}

1. Terdapat dua faktor yang mempengaruhi wisatawan mancanegara memilih moda transportasi sepeda motor. Faktor tersebut antara lain:

a. Faktor Eksternal, yang terdiri dari: Lebar Jalan, Kemudahan Untuk Menyewa, Ketersediaan Ruang Parkir, Cepat, Kepadatan Lalu Lintas, Biaya Transportasi, dan Keandalan.

b. Faktor Internal, yang terdiri dari Rekomendasi Keluarga, Kemudahan Untuk Digunakan, Kepemilikan SIM, Anggaran, dan Jangkauan.

2. Faktor dominan yang mempengaruhi wisatawan mancanegara memilih moda transportasi sepeda motor adalah Faktor Eksternal. Faktor Eksternal memiliki nilai eigenvalue sebesar 6.031 dan percent of variance sebesar 50.258

\section{Saran}

1. Pemerintah perlu memperhatikan lebar jalan yang terdapat di kawasan Kuta Selatan dkarenakan tergolong sempit untuk kawasan pariwisata dan berpotensi terjadi penumpukan kendaraan.

2. Pemerintah perlu mengkaji regulasi mengenai lalu lintas yang nantinya dapat 
berdampak pada kepadatan lalu lintas di kawasan Kuta Selatan.

3. Perlu adanya transportasi publik yang efisien, aman, dan terjangkau bagi wisatawan sehingga tidak terjadi penumpukan jumlah kendaraan di kawasan Kuta Selatan dan dapat menekan angka kecelakaan.

4. Pihak penyewaan sepeda motor hendaknya mempertegas aturan penyewaan dengan memberikan syarat diperlukannya Surat Izin Mengemudi berstandar internasional maupun Surat Izin Mengemudi Sementara untuk warga negara asing yang bisa didapatkan di kantor polisi terdekat. 


\section{Kepustakaan}

Badan Pusat Statistik. 2018. Jumlah Kendaraan Sepeda Motor di Kota Kabupaten Bali Tahun 2017.

Badan Pusat Statistik. 2018. Panjang Jalan di Provinsi Bali Tahun 2017.

Hair et. al. 2010. Multivariate Data Analysis. Cetakan Ketujuh. United States of America: Pearson.

Mathieson, A. \& Wall, G. 1982. Tourism: Economic, Physical, and Social Impacts. London: Longman.

Roberts, K. W., 2012. Key Factrors and Trends in Transportation Mode and Carrier Selection. Tennessee: Thesis University of Tennessee.

Seaton, A.V.\& Bennet, M.M. The Marketing of Tourism Products: Concepts, Issues, and Cases. Haryana: International Thompson Business Press.

Suwena, I. K. \& Widyatmaja, I. G. N., 2010. Pengetahuan Dasar Ilmu Pariwisata. Denpasar: Udayana University Press

Swarbrooke, J. \& Horner, S. 1999. Consumer Behavior in Tourism. Oxford: Butterworth Heinemann

Tamin, O.2002. Perencanaan dan Permodelan Transportasi. Bandung: Penerbit ITB. 